\title{
Nursing care to patients with diabetes based on King's Theory
}

\author{
Cuidado de enfermagem ao paciente com diabetes fundamentado na Teoria de King \\ Cuidado de enfermería al paciente con diabetes justificado en la Teoría de King
}

\section{Eline Saraiva Silveira Araújo', Lúcia de Fátima da Silva', Thereza Maria Magalhães Moreira', Paulo César de Almeida', Maria Célia de Freitas', Maria Vilani Cavalcante Guedes'}

'Universidade Estadual do Ceará, Health Sciences Center. Fortaleza, Ceará, Brazil.

How to cite this article:

Araújo ESS, Silva LF, Moreira TMM, Almeida PC, Freitas MC, Guedes MVC. Nursing care to patients with diabetes based on King's Theory. Rev Bras Enferm [Internet]. 2018;71(3):1092-8. DOI: http://dx.doi.org/10.1590/0034-7167-2016-0268
Approval: 04-05-2017

\section{ABSTRACT}

Objective: To verify the effectiveness of nursing interventions based on the Imogene King's Theory of Goal Attainment, on improving care for people with diabetes and adherence to treatment. Method: Quasi-experimental, longitudinal, randomized, simple study in a Primary Health Care Unit, in the city of Fortaleza, Ceará state, Brazil. The sample consisted of 60 people with diabetes, divided into intervention and control groups, whose collection occurred from February to August 2013. Results: In the intervention group, a significant adherence of the patients to the goals defined in the study was found. In the control, there was improvement in some aspects of the treatment. Conclusion: With these results, it was possible to conclude the feasibility of using Theory of Goal Attainment in the positive aspects for adherence to diabetes treatment and improvement of quality of life. Descriptors: Nursing Theory; Primary Health Care; Diabetes Mellitus; Nursing Care; Nursing.

\section{RESUMO}

Objetivo: Verificar a efetividade de intervenções em enfermagem, fundamentada na Teoria do Alcance de Metas de Imogene King, na melhoria do cuidado à pessoa com diabetes e na adesão ao tratamento. Método: Estudo quase-experimental, do tipo longitudinal, randomizado simples, numa Unidade de Atenção Primária à Saúde, no município de Fortaleza, Ceará, Brasill. A amostra contou com 60 pessoas com diabetes, divididas nos grupos de intervenção e controle, cuja coleta ocorreu de fevereiro a agosto de 2013. Resultados: No grupo de intervenção, encontrou-se uma adesão significativa dos pacientes às metas definidas no estudo. No controle, houve melhora em alguns aspectos do tratamento. Conclusão: Com esses resultados pôde-se concluir a viabilidade do emprego da Teoria do Alcance de Metas nos aspectos positivos para a adesão ao tratamento do diabetes e melhoria da qualidade de vida.

Descritores: Teoria de Enfermagem; Atenção Primária à Saúde; Diabetes Mellitus; Cuidados de Enfermagem; Enfermagem.

\section{RESUMEN}

Objetivo: Comprobar la efectividad de intervenciones en enfermería, justificada en la Teoría del Alcance de Metas de Imogene King, en el perfeccionamiento del cuidado a la persona con diabetes y en la adhesión al tratamiento. Método: Estudio cuasi experimental, de naturaleza longitudinal, aleatorizado simple, en una Unidad de Atención Primaria a la Salud, en el municipio de Fortaleza, Ceará, Brasil. La muestra incluyó 60 personas con diabetes, divididas en los grupos de intervención y control, cuya recolección ocurrió de febrero a agosto de 2013. Resultados: En el grupo de intervención, se encontró una adhesión significativa de los pacientes a las metas definidas en el estudio. En el control, hubo una mejora en algunos aspectos del tratamiento. Conclusión: Con estos resultados se pudo concluir la viabilidad del empleo de la Teoría del Alcance de Metas en los aspectos positivos para la adhesión al tratamiento de la diabetes y mejora de la calidad de vida.

Descriptores: Teoría de Enfermería; Atención Primaria a la Salud; Diabetes Mellitus; Cuidados de Enfermería; Enfermería. 


\section{INTRODUCTION}

The chronic disease, associated with various complications, Diabetes Mellitus (DM) is one of the main causes of mobimortality in the population. An international study points to diabetes as one of the greatest health emergencies of the 21st century. According to estimates, there are 415 million people worldwide with DM projected to increase from this total to 642 million in $2040^{(1)}$.

In Brazil, the great magnitude of Chronic Noncommunicable Diseases (NCD) corresponds to $72 \%$ of the causes of deaths, and the number of deaths due to diabetes is increasing ${ }^{(2)}$. Type 2 diabetes mellitus is a cause of concern, particularly because of the risk of developing micro and macrovascular complications that reduce patients' expectations and quality of life ${ }^{(3)}$.

In this context, health professionals aim to control this disease through the adherence of the people affected by it to the health promotion and maintenance care, especially by encouraging them to take healthy behaviors, modify their lifestyle and follow the treatment.

Nurses, in particular, have the challenge of providing assistance to individuals, families and communities through direct or indirect care. It is up to you to develop care in interaction with these patients, helping to understand the need to make changes in lifestyle. Thus, they may contribute to their adherence to glycemic control.

In turn, Nursing Theories base the care with their own knowledge, in order to improve the quality of care provided to people in different fields of knowledge.

One of these theories, King's Goal Attainment, describes the nature of the nurse-patient relationship for reaching goals, which are implemented in a process of interaction through communication. To do so, the nurse's evaluation with this patient is used, especially in the identification of problems, health disorders, their perceptions of problems and sharing of information to plan the strategies to reach the goals proposed by agreement $t^{(4-5)}$.

In view of the relevant and necessary nurse-patient interaction for the improvement of care for people with DM in Primary Health Care, the question is: How effective are nursing interventions, based on Theory of Goal Attainment on improving care for person with diabetes and in their adherence to treatment?

Thus, this research can generate support for a nurse-patient interaction that can effectively contribute to the improvement of their quality of life.

\section{OBJECTIVE}

To verify the effectiveness of nursing interventions, based on Theory of Goal Attainment, improving care for people with diabetes and adherence to treatment.

\section{METHOD}

\section{Ethical aspects}

The project was approved by the Research Ethics Committee of the Universidade do Estado do Ceará. All participants signed the Free and Clarified Consent Term (FCCT) prior to the start of data collection, respecting the ethical precepts of research with human beings based on Resolution 466/12 of the National Health Council ${ }^{(6)}$.

\section{Design, place of study and period}

It is a quasi-experimental study, type before and after an intervention. In this study, goals based on King's theory were drawn, based on the problems detected in the nursing consultations for people with diabetes mellitus with a view to better adherence to treatment in a Family Health Strategy team in the city of Fortaleza, Ceará state, Brazil. from February to August 2013.

\section{Population}

Patients who met the following criteria were included in the study: being regularly enrolled and followed by the team; being 18 years of age or older, of both sexes and having a diagnosis of diabetes referred for at least six months. We excluded those with cognitive deficit and with difficulties that could make the communication and the responses to the instrument unfeasible.

The sample of the present study was obtained through convenience sampling and was composed of 60 people with DM enrolled in the hypertension and diabetes program in that unit. Out of 60 patients, there were two deaths and two deaths due to change of address.

\section{Study protocol}

With all the patients participating in the research, data for the baseline were collected at the first nursing visit for purposes of future comparisons. These data were collected and recorded in a form containing sociodemographic information (sex, age, years of study and family income), family, clinics (diagnosis time, comorbidities and chronic complications), metabolic control (BMI, abdominal pressure, blood pressure), lifestyle, general health perception/monitoring, self/body image, time, human interactions, role and relationship, nutrition and metabolism, eliminations, sleep and rest, sexuality and reproduction.

After this consultation, the patients were divided into two groups, which were submitted to three more nursing consultations: the intervention group, which passed the nursing consultation based on the Theory of Goal Attainment, when, at each consultation, goals were drawn based on the problems detected, in agreement with each patient attended. With each return, the same goals were maintained when they could not achieve them, and/or new goals were set. As the consultations were individualized not all dyads established the same goals, and these were designed according to the needs of each patient. The form used in the consultations also contained the decisions made in the nurses-patient interaction process, jointly established goals, subsequent evaluations and final evaluation.

Like the intervention group, the control group underwent three nursing consultations, and these routine consultations were already developed by the Family Health Strategy nurse. There was also a form to record the problems detected and their evolution throughout the consultations.

Data were collected individually during four visits by the researcher every 45 days. The average duration of each visit was forty minutes. 


\section{Data analysis and statistics}

For the analysis of blood pressure, capillary glycemia and BMI data, the parameters proposed by the Brazilian Diabetes Society (Sociedade Brasileira de Diabetes) (7) were followed.

The data were organized in a database in the program Excel for Windows and later, transported to the software SPSS version 20.0 (Statistical Package for the Social Sciences) $n^{\circ} 10101113007$, where they were processed for analytical statistical evaluation, the relation and interlacing of the diverse variables of the data, using non-parametric Chisquare tests and the likelihood ratio, adopting a statistical significance level of $5 \%$ ( $p<0.05)$.

\section{RESULTS}

Out of 60 patients with diabetes in the present study, the age ranged from 35 to 87 years, with an average age of 67.2 years. Of these, $76.7 \%$ were female and $50.0 \%$ were married. As for schooling, an average of 4.1 years of study and a family income of 2.9 minimum wages was obtained. As for the time of diagnosis, $40.0 \%$ was up to five years and the average was 10.3 years. The main comorbidities were: arterial hypertension $(76.7 \%)$, dyslipidemia $(43.3 \%)$ and obesity $(30.0 \%)$. These patients were divided into the intervention group and the control group. However, with the non-parametric Chisquare test and the likelihood ratio, a statistical significance level of $5 \%$ ( $p<0.05)$ was not found to be statistically significant. Table 1 presents the data related to the goals reached and not reached for the intervention group.

As shown in Table 1, the goal of starting the use of sweetener/ withdrawing sugar from the diet was established by agreement between the three consultations and was reached consecutively by $90.9 \%, 84.6 \%$ and $85.7 \%$ of patients.

Regarding the practice of physical activity in the control of diabetes in this study, the goal was to achieve the beginning/resumption of physical activity, reached by $30.8 \%, 33.3 \%$ and $66.7 \%$ of the participants. Regarding the regular use of oral medication and/ or insulin by the patients in this study, the goal was established and reached by $66.7 \%, 100.0 \%$ and $100.0 \%$ of them.

In adherence to a balanced diet, in this study, the goal was to control hypercaloric foods. As observed, $25.0 \%, 60.0 \%$ and $100.0 \%$ were able to adhere to the hypocaloric diet. When consumed in excess, carbohydrates cause weight gain, hyperglycemia and fat accumulation. The importance of controlling the amount of carbohydrates was clarified to patients; then, $80.0 \%, 87.5 \%$, and $88.9 \%$ achieved this standard.
Regarding fruit consumption, the goal was a daily intake of fruits, which had adhesion of $66.7 \%, 100.0 \%$ and $100.0 \%$ of the patients. Regarding the consumption of refrigerant, $80.0 \%$, $85.7 \%$ and $85.7 \%$ of the patients complied with it. Regarding weight loss, although obesity is a worldwide reality, weight loss was observed for $50.0 \%, 75.0 \%$ and $75.0 \%$ of the patients.

We know the importance of the multidisciplinary team and the role of nutritionist in supporting family health teams to follow patients with diabetes. Despite the implementation of these teams, not all have this professional. As a follow-up by the nutritionist, and diabetes being directly related to food, the goal was to consult with this professional, which was performed by $50.0 \%, 33.3 \%$ and $50.0 \%$ of the patients.

Hyperglycemia or poor glycemic control is still present in several patients, due to several factors already mentioned. However, in order to improve this, in view of its repercussions in the future, it has been defined as a goal for patients with hyperglycemia, its reduction. Then, $66.7 \%, 100.0 \%$ and $100.0 \%$ of them reached it.

Regarding the stressors that indirectly influence the glycemic control, referred to as daily family or work problems, it was suggested the non-confrontation with these aggressive agents. However, only $33.3 \%, 0.0 \%$ and $60.0 \%$ achieved this goal.

Regarding the variables associated with the problems detected for the control group, the data are shown in Table 2. 
Nursing care to patients with diabetes based on King's Theory Araújo ESS, Silva LF, Moreira TMM, Almeida PC, Freitas MC, Guedes MVC.

Table 2 - Analysis of the problems detected for the control group, Fortaleza, Ceará state, Brazil, February to August, 2013, N = 30

\begin{tabular}{|c|c|c|c|c|c|c|}
\hline \multirow{3}{*}{ Problem } & \multicolumn{2}{|c|}{$1^{\text {st }}$ comeback } & \multicolumn{2}{|c|}{$2^{\text {nd }}$ comeback } & \multicolumn{2}{|c|}{$3^{\text {rd }}$ comeback } \\
\hline & Imp & Mant & Imp & Mant & Imp & Mant \\
\hline & $\%$ & $\%$ & $\%$ & $\%$ & $\%$ & $\%$ \\
\hline No problems & 0 & $\begin{array}{c}4 \\
100\end{array}$ & 0 & $\begin{array}{c}4 \\
100\end{array}$ & 0 & $\begin{array}{c}4 \\
100\end{array}$ \\
\hline Sedentarism & $\begin{array}{c}2 \\
14.3\end{array}$ & $\begin{array}{c}12 \\
85.7\end{array}$ & $\begin{array}{c}3 \\
18.8\end{array}$ & $\begin{array}{c}13 \\
81.3\end{array}$ & $\begin{array}{c}06 \\
37.5\end{array}$ & $\begin{array}{c}10 \\
62.5\end{array}$ \\
\hline Control/loss of weight & $\begin{array}{c}3 \\
75.0\end{array}$ & $\begin{array}{c}1 \\
25.0\end{array}$ & $\begin{array}{c}3 \\
75.0\end{array}$ & $\begin{array}{c}01 \\
25.0\end{array}$ & $\begin{array}{c}3 \\
60.0\end{array}$ & $\begin{array}{c}2 \\
40.0\end{array}$ \\
\hline Overweight/ obesity & 0 & $\begin{array}{c}8 \\
100\end{array}$ & 0 & $\begin{array}{c}09 \\
100\end{array}$ & 0 & $\begin{array}{c}9 \\
100\end{array}$ \\
\hline Hyperglycemia & 0 & $\begin{array}{c}4 \\
100\end{array}$ & $\begin{array}{c}1 \\
16.7\end{array}$ & $\begin{array}{c}05 \\
83.3\end{array}$ & $\begin{array}{c}1 \\
14.3\end{array}$ & $\begin{array}{c}6 \\
85.7\end{array}$ \\
\hline Regular use of medication & 0 & $\begin{array}{c}2 \\
100\end{array}$ & $\begin{array}{c}4 \\
100\end{array}$ & 00 & $\begin{array}{c}4 \\
100\end{array}$ & 0 \\
\hline Excessive diet & 0 & $\begin{array}{c}1 \\
100\end{array}$ & $\begin{array}{c}2 \\
66.7\end{array}$ & $\begin{array}{c}01 \\
33.3\end{array}$ & $\begin{array}{c}2 \\
66.7\end{array}$ & $\begin{array}{c}1 \\
33.3\end{array}$ \\
\hline Sugar and candies consumption & $\begin{array}{c}2 \\
33.3\end{array}$ & $\begin{array}{c}4 \\
66.7\end{array}$ & $\begin{array}{c}3 \\
50.0\end{array}$ & $\begin{array}{c}03 \\
50.0\end{array}$ & $\begin{array}{c}4 \\
57.1\end{array}$ & $\begin{array}{c}3 \\
42.9\end{array}$ \\
\hline Usually smoking & 0 & $\begin{array}{c}3 \\
100\end{array}$ & $\begin{array}{c}1 \\
33.3\end{array}$ & $\begin{array}{c}02 \\
66.7\end{array}$ & 0 & $\begin{array}{c}3 \\
100\end{array}$ \\
\hline
\end{tabular}

Note: Imp - improved; Mant - mantained the problem.

For the participants in the control group, as shown in Table 2, an improvement in the detected problems was observed; as it is believed, this is due to the interaction and the closest follow-up to the patient adopted in the research and by the greater proximity in the consultations. Even without having established goals, knowing that they were participating in the research, there was a greater adherence to healthy living habits.

As for sedentarism, it was followed up in the three subsequent consultations and among these, $14.3 \%, 18.8 \%$ and $37.5 \%$ started to practice physical activities. Regarding weight control/loss, $75.0 \%, 75.0 \%$ and $60.0 \%$ improved, but still remained in overweight/obesity indexes, and there was no improvement in any patient.

In those with high glycemic values, it was observed in the subsequent consultations that $0.0 \%, 16.7 \%$ and $14.3 \%$ improved glycemic indexes and were within the standards recommended by the Ministry of Health. Regarding the irregular use of the medication, common practice of people with diabetes, in this study group, $0.0 \%, 100.0 \%$ and $100.0 \%$ started to use the medication regularly.

An excessive diet was identified early in a patient in this group who maintained the practice, and in the subsequent two consultations improved food control in $66.7 \%$ repeatedly. Regarding sugar, as observed, $33.3 \%, 50.0 \%$ and $57.1 \%$ of the patients abandoned their use. However, the frequency of consumption of sweet foods on five or more days of the week was $21.5 \%$.

Those that affirmatively said, about the habitual use of smoking in the second consultation, one abandoned, but in the subsequent consultation already had returned to consume it. Therefore, no patient was adhered to it.

\section{DISCUSSION}

To develop this study, we sought to build on the Imogene King's Theory of Goal Attainment. This describes the nature of nurse-patient interactions that lead to goal achievement, in which nurses purposefully interact with patients to mutually establish goals, explore and agree on ways to achieve them. Mutual goals are based on the identification of problems, changes in health, perceptions of problems and sharing of information in order to achieve goals ${ }^{(4)}$.

Patients from the intervention group were analyzed separately on the basis of the goals agreed upon in the nursing consultations based on the Imogene King's Theory of Goal Attainment. Regarding the sociodemographic and clinical characterization of the sample, the findings are similar to those of other studies conducted in Brazil on the prevalence of diabetes mellitus ${ }^{(2,8)}$.

In the interaction process of theory, this is defined as a process of perception and communication between the person and the environment, and between people, represents a sequence of verbal and nonverbal behaviors that are meta-oriented. Each individual brings knowledge, needs, goals, expectations, perceptions and experiences that influence the interactions ${ }^{(4)}$.

Regarding the findings related to the goals proposed for the intervention group (Table 1), the goal of initiating the use of sweetener/withdrawing sugar from the diet was established and achieved by most patients. We know of the difficulties of withdrawing sugar from food, because it requires changes in daily personal and family habits, and adherence to a more restricted diet. Each patient's perception of goal adherence is an action oriented in the present, and can be influenced by current interests, needs and future goals.

Behavioral changes and adherence to medication treatment are fundamental to prevent acute and chronic complications in the medium and long term ${ }^{(8-9)}$. The professional should negotiate priorities, monitor adherence, motivate participation and stimulate patient effort in managing their treatment. Even when these changes occur, maintaining metabolic control for a long time is complicated because it depends on several components involved in the treatment of diabetes.

Adherence to regular use of medication is still a challenge for health, especially in people with diabetes, and when it comes to the use of insulin this becomes even more acute. Difficulties were perceived in the course of this study, especially in the restricted dispensation of drugs in primary care. Also, due to the irrelevant importance attributed to the medication by the patients, by their signs and symptoms not apparent, and the low income of the population, many do not prioritize the purchase of medication and do not use it. However, by empowering treatment, they feel co-responsible, and adherence rates improve.

In a study conducted in Minas Gerais state, with 1,406 patients with diabetes, adherence to drug treatment was over 
$60 \%$ in all health units investigated, and reached a percentage of up to $93.9 \%{ }^{(10)}$. In cases of irregular consumption of medication, it is fundamental to draw up strategies for individual interventions, identifying the main complaints referred by patients and the support of the multiprofessional health team, in order to achieve adherence to medication treatment. In the theory under study, one of its concepts is perception, as a process of organization, interpretation and transformation of information from sensory data and memory, which influences client behavior and health goals $s^{(4)}$.

As evidenced, the low level of education of people with diabetes may make it difficult for them to understand essential care for disease control and prevention of complications. For some authors, this is considered to be a determinant for people who need an elaborate care plan on food re-education, physical activity and drug treatment ${ }^{(11)}$. In this plan, communication is necessary because it is a powerful tool in the care process, above all because it provides an effective relationship with the patient ${ }^{(12)}$. A shared approach between patient and health care practitioner can bridge these gaps in knowledge. It is essential for nurses to be aware of their perceptions, especially for assisting, interpreting and elaborating the therapeutic plan.

It is up to the health professional to systematize his intervention for the empowerment of the patients. The follow-up of these by experts in diabetes, with feasible guidelines and targets is decisive in the reduction of glycemia, glycated hemoglobin and smoking. Type 2 DM can be delayed or prevented, with lifestyle modifications, including diet and physical activity ${ }^{(7)}$.

Achieving the goals proposed in the treatment of diabetes requires effort of the health team composed of educators in diabetes mellitus, specialized nutritionist and the person with diabetes ${ }^{(7)}$. At present, the care of patients with diabetes provided by a multiprofessional team aims to get you to understand the importance of lifestyle modification for good metabolic control.

As for adherence to the food plan, it was low in the units evaluated in this study. It is recognized that this is one of the greatest challenges faced by the Family Health Strategy teams due to the inherent complexity of eating behavior ${ }^{(10)}$. For better adherence to this goal, communication should be established in an atmosphere of mutual respect and desire for understanding, when one of the elements in communication is listening, and requiring individuals who actively participate in verbal exchange ${ }^{(4)}$.

As proposed, the use of appropriate language can induce patients to plan their meals, comply with schedules and the food plan, and encourage them to practice physical activities ${ }^{(13)}$. The construction of new knowledge leads to the acquisition of preventive behaviors and stimulus to the management of their disease. Therefore, the nurse needs to be closely linked to the educational resources, because the caring process is linked to that of educating.

However, as evidenced, the diet of most Brazilians includes many carbohydrates because it is low cost and easier to access, unlike the diet with fruits and vegetables still consumed in a restricted way. Nurses play a crucial role in health organizations with active participation in decision making that influence the quality of care ${ }^{(4)}$.
Regarding fruit consumption, the Ministry of Health, at the national level, recommends the consumption of larger quantities of fruits and vegetables and a lower amount of fats, sugars and salt, since they have profound implications for health and quality of life of people. Also, three servings of fruits per day are recommended ${ }^{(14)}$. It is suggested to divide the food plan into six meals, three main and three snacks. As for the preparation of food, grilled, baked, steamed or even raw ${ }^{(7)}$ should be preferred. Nowadays, the consumption of soft drinks is a common practice, due to its easy access, low cost and non-disclosure of its health risks, due to its amount of sugar, sodium, dyes, among others. You have to avoid it.

Structured programs that emphasize lifestyle changes, such as nutritional education, fat and energy restriction, associated with physical activity and monitoring by health professionals, can lead to long-term weight loss of around $5 \%$ to $7 \%$ of body weight ${ }^{(7)}$. For health-care organizations, the goal is to help individuals maintain their health, regain it if they have any health problems, prevent disease return if possible, and learn how to deal with chronic diseases ${ }^{(4)}$.

The importance of the practice of physical activity in the control of diabetes is cited, but its adherence is still slowly achieved by the patients. According to the theory under analysis, although each human being is unique, a group of people can observe the same event, but each one can perceive it differently ${ }^{(4)}$. However, patients' difficulties in adopting this practice may be related to lack of incentive or even accommodation.

Associated with the dietary plan, physical activity may be beneficial to assist in glycemic control, weight loss and increased muscle mass ${ }^{(7)}$. As noted, glycemic control is reported as one of the main difficulties encountered by patients in changes in daily activity practices. Even with the proximity of nursing consultations, in which they would be evaluated more frequently, they still can not reduce glycemic values.

In a study of patients attended at the Hospital das Clínicas of Ribeirão Preto-São Paulo state, a substantial portion of the $79.0 \%$ sample had high fasting plasma glucose $\mathrm{e}^{(15)}$. Factors that can directly influence the treatment are the overweight and obesity of the patients, as they make it difficult to practice physical activities, as well as adherence to the food plan. Obesity is a worldwide reality. According to data from the Ministry of Health, the frequency of overweight was $52.2 \%$ in the adult population of the 27 Brazilian cities and $16.8 \%$ in the obese population ${ }^{(16)}$.

According to a study, $84.4 \%$ of the patients had adherence to the drug treatment, $58.6 \%$ to physical exercise and $3.1 \%$ to the food plan. Only $1.4 \%$ adhered to the three components of treatment. Adherence to drug treatment and physical exercise were observed for $47.7 \%$ of the patients. As noted, $43.0 \%$ adhered to a single component of treatment and $6.2 \%$ to none ${ }^{(10)}$.

For the health professional to develop health education in a more comprehensive and interventional way, it is important to be involved with patients, their problems, their joys, their everyday knowledge and their social reality ${ }^{(13)}$. In the national and international scenario, noncompliance with the treatment of diabetes mellitus is a known problem because it impairs the physiological response to the disease, the professionalpatient relationship, and increases the direct and indirect cost of treatment ${ }^{(8-9)}$. 
The first purpose of nursing is to assist the patient in the fight against a health problem or regarding health. When the nursepatient dyad identifies goals to be achieved, the interactions are focused on these goals and a positive interpersonal relationship begins to establish ${ }^{(4)}$. The health variables monitored and evaluated during the study allow us to affirm the validity of Theory of Goal Attainment as the basis for nursing care for patients with diabetes in the context of Primary Health Care. At the end of the study, according to the authors, it can be stated on the basis of this theory that the objective was reached because the theory proposal promoted better adherence of the patients to the treatment suggested in agreement with them.

\section{Study limitations}

We noticed some limitations, related to the development time of the research; the lack of structure in the support network for Family Health teams, and social spaces to develop physical and group activities; and cultural issues of eating habits.

\section{Contributions to the area of Nursing, health or public policy}

We emphasize that the Family Health Strategy nurse can use it as an instrument of care, in order to provide professionals with effective means to assist the patient with diabetes.

\section{CONCLUSION}

The theory proposed by Imogene King for the achievement of goals is feasible to be applied in the Family Health Strategy, since the patient feels co-responsible for his treatment, and acts actively with decisive power in the possible changes for better adherence to the proposed care. In addition, because it is always accompanied by the same team, interaction

When comparing the results of this interaction based on the theory employed, it is considered that the objective was reached, mainly because of the significant adherence to the use of sweetener, to the practice of physical activity, regular use of medication and food control.

Still as identified in the two study groups, the monitoring with a greater proximity of time promoted a positive surveillance, since, due to the greater interaction of both, it was possible to better adapt the strategies of adherence to the proposed treatment with consequent promotion of the quality of people with diabetes.

In this perspective, before the results found, this study is concluded with the confidence that the nursing clinical care positively favors the people, with a view to improving the nursing care directed to them.

\section{REFERENCES}

1. Internacional Diabetes Federation. IDF Diabetes Atlas [Internet]. $7^{\text {th }}$ ed. Brussels, Belgium: IDF; 2015. [cited 2016 Jan 20]. Available from: www.diabetesatlas.org

2. Brasil. Ministério da Saúde. Secretaria de Vigilância em Saúde. Departamento de Análise de Situação de Saúde. Plano de ações estratégicas para o enfrentamento das doenças crônicas não transmissíveis (DCNT) no Brasil 2011-2022 [Internet]. Brasília: Ministério da Saúde; 2011. [cited 2016 Jan 20]. Available from: http://bvsms.saude.gov.br/bvs/publicacoes/plano_acoes_enfrent_ dent 2011.pdf

3. Araújo MFM, Araújo TM, Alves PJS, Veras VS, Zanetti ML, Damasceno MMC. Drug use, blood glucose and body mass index in patients with diabetes mellitus. Rev Bras Enferm [Internet]. 2013 [cited 2016 Jan 20];66(5):709-14. Available from: http://www. scielo.br/pdf/reben/v66n5/11.pdf

4. King JM. A theory for nursing: systems, concepts, process. Tampa, Florida: Delmar Publishers; 1981.

5. Leopardi MT. Teoria e método em assistência de enfermagem. 2.ed. Florianópolis: Soldassoft; 2006.

6. Brasil. Ministério da Saúde. Conselho Nacional de Saúde. Resolução 466 de 12 de dezembro de 2012: diretrizes e normas regulamentadoras da pesquisa envolvendo seres humanos [Internet]. Brasília: Ministério da Saúde, 2012[cited 2016 Jan 20]. Available from: http://conselho.saude.gov.br/resolucoes/2012/Reso466.pdf

7. Sociedade Brasileira de Diabetes. Diretrizes da Sociedade Brasileira de Diabetes. 7.ed. Itapevi, SP: AC Farmacêutica; 2015.

8. Faria HTG, Rodrigues FFL, Zanetti ML, Araújo MFM, Damasceno MMC. Factors associated with adherence to treatment of patients with diabetes mellitus. Acta Paul Enferm [Internet]. 2013 [cited 2016 Jan 20];26(3):231-7. Availabre from: http://www.scielo.br/ pdf/ape/v26n3/en_05.pdf

9. Arrelias CCA, Faria HTG, Teixeira CRS, Santos MA, Zanetti ML. Adherence to diabetes mellitus treatment and sociodemographic, clinical and metabolic control variables. Acta Paul Enferm [Internet]. 2015 [cited 2016 Jan 20];28(4):315-22. Available from: http://www.scielo.br/pdf/ape/v28n4/en_1982-0194-ape-28-04-0315.pdf

10. Faria HTG, Santos MA, Arrelias CCA, Rodrigues FFL, Gonela JT, Teixeira CRS, et al. Adherence to diabetes mellitus treatments in Family Health Strategy Units. Rev Esc Enferm USP [Internet]. 2014 [cited 2016 Jan 20];48(2):257-63. Availabre from: http://www. scielo.br/pdf/reeusp/v48n2/0080-6234-reeusp-48-02-257.pdf

11. Sacerdote $\mathrm{Cl}$, Ricceri F, Rolandsson O, Baldi I, Chirlaque MD, Feskens E. Lower educational level is a predictor of incident type 2 diabetes in European countries: the EPIC-Inter Act study. Int J Epidemiol [Internet]. 2012 [cited 2015 Jul 15];41(4):1162-73. Availabre from: http://www.ncbi.nlm.nih.gov/pubmed/22736421

12. Broca PV, Ferreira MA. Communication process in the nursing team based on the dialogue between Berlo and King. Esc Anna 
Nery Rev Enferm [Internet]. 2015 [cited 2016 Jan 20];19(3):467-74. Available from: http://www.scielo.br/pdf/ean/v19n3/en_14148145-ean-19-03-0467.pdf

13. Torres HC, Roque C, Nunes C. Visita domiciliar: estratégia educativa para o autocuidado de clientes diabéticos na atenção básica. Rev Enferm UERJ [Internet]. 2011 [cited 2016 Jan 20];19(1):89-93. Available from: http://www.facenf.uerj.br/v19n1/v19n1a15.pdf

14. Brasil. Ministério da Saúde. Secretaria de Atenção à Saúde. Departamento de Atenção Básica. Guia alimentar para a população brasileira [Internet]. Brasília: Ministério da Saúde, 2014. [cited 2016 Jan 20]. Availabre from: http://bvsms.saude.gov.br/bvs/ publicacoes/guia_alimentar_populacao_brasileira_2ed.pdf

15. Boas LCG-V, Foss-Freitas MC, Pace AE. Adesão de pessoas com diabetes mellitus tipo 2 ao tratamento medicamentoso. Rev Bras Enferm [Internet]. 2014 [cited 2016 Jan 20];67(2):268-73. Available from: http://www.scielo.br/pdf/reben/v67n2/0034-7167reben-67-02-0268.pdf

16. Brasil. Ministério da Saúde. Secretaria de Vigilância em Saúde. Vigitel Brasil 2014: vigilância de fatores de risco e proteção para doenças crônicas por inquérito telefônico [Internet]. Brasília: Ministério da Saúde, 2015 [cited 2016 Jan 20]. Available from: http://bvsms.saude.gov.br/bvs/publicacoes/vigitel_brasil_2014.pdf 